\title{
Exploring critical success factors for stakeholder management in small ruminant farming
}

\begin{abstract}
The aim of this study was to determine the Critical Success Factor (CSF) in small ruminant farming. A total 600 respondents were surveyed in the field. Face to face interviewed used as a method of this study. The results from factor analysis revealed that the small ruminant farming ranchersôperspectives, thirteen (13) factors were extracted namely family support, government support and policies, labour, extension services, production system, farm management, feed sources, farm operation, neighborhood relationship, marketing, disease and prevention management, feed strategies and technical skill. All these factors family support, government support and policies, labour, extension services, production system and farm management were identified as critical successful factors among the respondents to perform success in small ruminant farming.
\end{abstract}

Keyword: Critical success factor; Goat; Livestock industry; Management; Sheep 